\title{
Factors that Affect the Adhesion of Probiotics Bacteria to Resist Rice Starch
}

\author{
Ghalia Salem M. Eswai (Corresponding author) \\ Faculty of Science and Technology, UniversitiSains Islam Malaysia (USIM) \\ Bandar BaruNilai, 71800 NilaiNegeri Sembilan, Malaysia \\ Tel: +60178826280Ｅ-mail: ghaliaeswai@yahoo.com
}

Zaiton Hassan

Faculty of Science and Technology, UniversitiSains Islam Malaysia (USIM)

Bandar BaruNilai, 71800 NilaiNegeri Sembilan, Malaysia

E-mail: drzaiton@usim.edu.my

Maryam A. S. Abubakr

Faculty of Science and Technology, UniversitiSains Islam Malaysia (USIM)

Bandar BaruNilai, 71800 NilaiNegeri Sembilan, Malaysia

E-mail: m.abubakr2008@yahoo.com

Received: July 30, 2012 Accepted: August 12, 2012

doi:10.5296/jbls.v4i1.2162 URL: http://dx.doi.org/10.5296/jbls.v4i1.2162

\begin{abstract}
Prebiotics such as resistant starch can be included with probiotics to increase their survival during processing. In this study lactic acid bacteria (LAB) isolated from several sources (yoghurt, banana, and human breast milk) were screened for their probiotic properties. Ten species of bacteria overcame the stress to $\mathrm{pH} 3$ and $0.3 \%$ bile. The adhesion properties of these LABs to resistant rice starch (RRS) were investigated. All 10 species of bacteria adhered to RRS within 60 min of exposure. Isolates Bn1 and HM2 were highly adhered to RRS with a total of $79 \%$ and $77 \%$ of the cells adhering, respectively. Moderate adherent
\end{abstract}


was observed by isolates, YN(70\%), CY(48\%), FY(55\%), HM1(61,5\%), HM3(65\%), and HM4(50,5\%), while isolate YD and Bn2 were poorly adhered to RRS (<40\%adherent). Bacteria adhesion to RRS was positively correlated to time but not to concentration. $37{ }^{\circ} \mathrm{C}$ was the ideal temperature for adhesion and Living cells are important for the adhesion.

Keywords: Probiotic, Adhesion, Resistant Starch, Lactic acid bacteria, Prebiotic

\section{Introduction}

Probiotics are live microorganisms that are created food supplements order to take advantage the health of the consumer by a positive impact on microbial balance in the intestine(Crittenden et al., 2001). Lactic acid bacteria, including Lactobacillus spp. And Bifidobacterium spp. become very popular in the dairy industry because of their therapeutic benefits. Some health benefits include improvement in intestinal disorders and lactose intolerance, altered vitamin content of milk, antagonism against various pathogenic organisms and antimutagenic and anti-carcinogenic activities. There is currently much interest in the concept of actively improving the host health by managing the colonic microflora. Traditionally, this has been attempted by using probiotics. An alternative approach is the consumption of food ingredients known as prebiotics (Rycroft et al., 2001).

Viability and stability of probiotics are both marketing and technological challenge for industrial producers. Probiotics to be functional, it must be viable and adequate dose levels (Galdeano \& Perdigón, 2004). Production of probiotic supplements for food / feed requires that strains to maintain an appropriate level of viable cells during product processing and shelf life. Once culture is determined desirable, technological demands placed on the strains of microorganisms are great and often has new manufacturing process and formulation technologies are needed for the survival and keep healthy and functional properties accordingly. Before being delivered strains of microorganisms in food / feed products, should survive and deal with stress factors and maintain the digestive system and its biological function within the host (Mattila-Sandholm et al., 2002).

Prebiotics are carbohydrates of comparatively short chain length (Cummings et al., 2001); additionally Carbohydrates that have escaped digestion in the upper gastrointestinal tract are the pillars of the dominant growth of bacteria in the colon (Roberfroid, 2001).

Some starches also can arrive to the colon as fermentable carbohydrate sources for intestinal bacteria without digestion when they are passing through the human small intestine (Cummings \& Macfarlane, 1997). Resistant starches synthesized by a number of food plants cannot digested completely because their size and molecular conformation (Vonk et al., 2000).

A group of human intestinal bacteria can ferment soluble starch; such as Bacteroides, Bifidobacterium, Fusobacterium, and Butyrivibrio (Macfarlane \& Englyst, 1986). Inclusion of resistant starches in the diet of animal models increases the population of bifidobacteria in the intestinal tract (Silvi et al., 1999). It has been shown that some intestinal bacteria can adhere to starch in vitro (Tancula et al., 1992). 


\section{Macrothink}

Journal of Biology and Life Science

ISSN 2157-6076

2013, Vol. 4, No. 1

The adhesion of bacteria depends on numerous factors, including morphological and physiological characteristics, the nature of the substrate and the environment (Fernando et al., 2011).

The current work examined the ability of LAB isolated from different sources with potential probiotic properties to adhere to several resistant rice starch granules in an attempt to understand the factors that affect adhesion of these LABs to resistant rice starch.

\section{Materials and Methods}

\subsection{Isolation of Lactic Acid Bacteria from Different Sources}

\subsubsection{Yoghurt and Fermented Banana}

Locally available fermented dairy products, namely: Yoghurt Natural (YN), Children Yoghurt (CY), Yoghurt Drink (YD), Fruit Yoghurt (FY), and Fermented banana, which all claimed to contain lactic acid bacteria (LAB), was used in this study as sources of LAB. Three (3) samples of each product were bought from the several supermarkets were obtained.10 $\mathrm{g}$ of sample was added to $90 \mathrm{~mL} 0.1 \%$ peptone water and appropriate dilution was spread plated on de Man, Rogosa and Sharpe (MRS) agar (Oxoid CM0361) plates containing 0.8\% calcium carbonate $\left(\mathrm{CaCO}_{3}\right)$. Plates were incubated anaerobically (in anaerobe jar using Oxoidanaerogen compact) at $37{ }^{\circ} \mathrm{C}$ for $48 \mathrm{~h}$. All bacterial strains were preserved in $15 \%$ glycerol stock then stored at $-20^{\circ} \mathrm{C}$. They were re-cultured in MRS broth (Oxoid CM0359) at $37{ }^{\circ} \mathrm{C}$ under anaerobic condition. Each bacterial strain was sub-cultured at least three times before the experiments $(1 \%, v / v)$ at $24 \mathrm{~h}$ (Kheadr, 2006).

\subsubsection{Human Breast Milk}

Sterile samples were collected from 10 healthy Mothers and then stored on ice until it is delivered to the laboratory. Then they were taken to the procedure for isolation. Isolation the organisms were by using Pour plate technique. Samples were used directly and also diluted to $10^{-1}, 10^{-2}$ and $10^{-3}$ using sterile peptone water. $1 \mathrm{ml}$ aliquot of the samples and dilutions were plated into MRS-cystein agar ( $\mathrm{pH}$ 5.5). The plates were incubated at $37^{\circ} \mathrm{C}$ for 3 days under anaerobic conditions (in anaerobe jar using Oxoidanaerogen compact) (Yavuzdurmaz, 2007).

\subsection{Probiotic Properties of Isolates}

\subsubsection{Oxbile Tolerance}

The tolerance of LAB strains to oxbile (Fluka Analytical 70168) was tested using sterile flat-bottom 96-well microtiter plate (Falcon, Becton Dickinson and Company, Frankin Lakes,NJ, USA). MRS broth (Oxoid CM0359) with 0.3\% w/v oxbile (Fluka Analytical 70168) was prepared, and $150 \mu \mathrm{L}$ was added to each well inoculated with $30 \mu \mathrm{L}$ of overnight culture previously diluted $1 / 1000$ in the same broth. Microplate was incubated anaerobically at $37^{\circ} \mathrm{C}$ for $24 \mathrm{~h}$. Optical densities were read at $600 \mathrm{~nm}$ using a biophotometer (Eppendorf Asia Pacific Sdn. Bhd) (Khaedr, 2006).

\subsubsection{Acid Challenge}




\section{Macrothink}

Journal of Biology and Life Science

ISSN 2157-6076

2013, Vol. 4, No. 1

Ten $\mathrm{mL}$ of mid-log-phase MRS cultures of each isolates were harvested by centrifugation at $6,000 \times \mathrm{g}$ for $15 \mathrm{~min}$ at $4^{\circ} \mathrm{C}$ (AllaegraTM 25R centrifuge, Beckman CoulterTM), added to an equal volume of MRS broth (Oxoid CM0359) (pH 2.0 using 1M HCl) (Fisher Scientific). Then they incubated anaerobically at $37^{\circ} \mathrm{C}$ for $60 \mathrm{~min}$. by diluting samples in peptone water (0.1\% w/v Liofichem 610038) and spread plating appropriate dilutions onto MRS agar viable counts were determined before and after incubation. Plates were incubated at $37^{\circ} \mathrm{C}$ for $48 \mathrm{~h}$ (anaerobically ) (Khaedr, 2006).

\subsubsection{Oxbile Challenge}

Ten $\mathrm{mL}$ of mid-log-phase MRS cultures of each isolates were harvested by centrifugation at $6,000 \times \mathrm{g}$ for $15 \mathrm{~min}$ at $4^{\circ} \mathrm{C}$, added to an equal volume of MRS broth ( $\mathrm{pH}$ 6.5) containing $0.3 \%(\mathrm{w} / \mathrm{v})$ oxbile. The resuspended cells were incubated anaerobically at $37^{\circ} \mathrm{C}$ for $90 \mathrm{~min}$. By diluting samples in peptone water $(0.1 \%, \mathrm{w} / \mathrm{v})$ and plating appropriate dilutions onto MRS agar (Oxoid CM0361) viable counts were determined before and after incubation. Then plates were incubated anaerobically at $37^{\circ} \mathrm{C}$ for $48 \mathrm{~h}$ (Khaedr, 2006).

\subsection{Determination of Adhesion Level by a Co-sedimentation Assay}

Determination of adhesion level by co-sedimentation assay followed the method of Crittenden et al. (2001). The cells were washed twice with $10 \mathrm{ml}$ of $0.1 \mathrm{M}$ phosphate buffer (pH 7.0) ,then they are suspended in the same buffer (concentration $=10^{7}$ cells $\mathrm{ml}^{-1}$ ). In a 1-cm-diameter test tube two milliliters of the bacterial suspension were mixed with an equal volume of a suspension of starch granules $\left(10 \mathrm{~g} \mathrm{liter}^{-1}\right)$ in $0.1 \mathrm{M}$ phosphate buffer ( $\left.\mathrm{pH} 7.0\right)$. The suspension was let for $1 \mathrm{~h}$ at room temperature to allow the starch to sediment. Two 1.5 $\mathrm{mL}$ samples were then taken from $0.5 \mathrm{~cm}$ below the liquid surface, and by a spectrophotometer the optical density was measured (at $540 \mathrm{~nm}$ ). Then find the result as follows:

Percentage of cells adhering to starch $=\mathrm{a}-\mathrm{b} / \mathrm{c}$

$\mathrm{a}=\mathrm{OD}_{540}$ of a sample containing starch plus bacteria.

$\mathrm{b}=\mathrm{OD}_{540}$ of a sample containing starch but no bacteria.

$\mathrm{c}=\mathrm{OD}_{540}$ of a sample containing bacteria but no starch.

Highly adherent (more than $70 \%$ of the cells adhered to the starch) as ( $40 \%$ to $70 \%$ adhesion) were named as moderate however less than $40 \%$ adhesion were named as poor adherent strains.

\subsection{The Influence of Time on the Adhesion of Bacteria to Starch Granules}

The method described in 2.5 was repeated. Adhesion of the bacteria to starch at $15 \mathrm{~min}, 30$ min, 45 min, and $1 \mathrm{~h}$ were determined.

\subsection{The Effect of Starch Concentration on the Adhesion of Probiotics}

The method described in 2.5 was repeated. The concentration of starch that was added to bacteria was varied at $10 \mathrm{~g} \mathrm{liter}^{-1}, 15 \mathrm{~g} \mathrm{liter}^{-1}$, and $20 \mathrm{~g} \mathrm{liter}^{-1}$. 
2.6 The effect of temperature on the attachment of probiotics to starch granules

The method described in 2.5 was repeated. Adhesion of the bacteria to starch was determined in body temperature (bt), heat-killed cells (hk), room temperature (rt).

\subsection{Influence of Growth Phase of Bacteria on Adhesion}

The method described in 2.5 was repeated. Adhesion of the bacteria to starch was determined with cells that were in the late lag phase $(6 \mathrm{~h})$, the exponential phase $(24 \mathrm{~h})$, and the mid-stationary phase (36 h).

\section{Results}

\subsection{Isolation of $L A B$}

39 bacteria were isolated from different sources. From those isolates 18 showed clear zone on modified $\mathrm{MRS}-\mathrm{CaCO}_{3}$ agar, catalase test negative and Gram positive and were considered as LAB.

Table 1. Phenotypic characteristics of LAB isolated

\begin{tabular}{|c|c|c|c|c|c|c|c|}
\hline NO. & Source & Code & $\mathrm{CaCO}_{3}{ }^{\mathrm{a}}$ & $\begin{array}{l}\text { Catalase } \\
\text { reaction }\end{array}$ & $\begin{array}{l}\text { Gram } \\
\text { reaction }\end{array}$ & $\begin{array}{c}\text { Gas } \\
\text { from } \\
\text { glucose }\end{array}$ & $\begin{array}{c}\text { Cell } \\
\text { morphology }\end{array}$ \\
\hline \multirow[t]{3}{*}{1} & $\begin{array}{l}\text { Yoghurt } \\
\text { Natural }\end{array}$ & YN1 & + & - & + & - & Rod \\
\hline & & YN2 & + & - & + & + & Coccid \\
\hline & & YN3 & + & - & + & + & Coccid \\
\hline 2 & $\begin{array}{l}\text { Children } \\
\text { Yoghurt }\end{array}$ & CY & + & - & + & - & Rod \\
\hline \multirow[t]{2}{*}{3} & $\begin{array}{l}\text { Yoghurt } \\
\text { Drink }\end{array}$ & YD1 & + & - & + & - & Short rod \\
\hline & & YD2 & + & - & + & + & Rod \\
\hline \multirow[t]{2}{*}{4} & $\begin{array}{c}\text { Fruit } \\
\text { Yoghurt }\end{array}$ & FY1 & + & - & + & - & Rod \\
\hline & & FY2 & + & - & + & & Rod \\
\hline \multirow[t]{5}{*}{5} & Banana & Bn1 & + & - & + & - & Short rod \\
\hline & & Bn2 & + & - & + & - & Rod \\
\hline & & Bn3 & + & - & + & + & Coccid \\
\hline & & $\mathrm{Bn} 4$ & + & - & + & + & Coccid \\
\hline & & Bn5 & + & - & + & + & Rod \\
\hline \multirow[t]{5}{*}{6} & $\begin{array}{c}\text { Human } \\
\text { Milk }\end{array}$ & HM1 & + & - & + & + & Short rod \\
\hline & & HM2 & + & - & + & + & Short rod \\
\hline & & HM3 & + & - & + & + & Rod \\
\hline & & HM4 & + & - & + & + & Rod \\
\hline & & HM5 & + & - & + & - & Coccid \\
\hline
\end{tabular}

$(+)$ positive, (-) negative

\subsection{Probiotic Properties of Isolates}

\subsubsection{Oxbile Tolerance}

Concentration of bile in the human gastrointestinal tract is different, and believed that the average concentration of bile in the intestine to be $0.3 \mathrm{w} / \mathrm{v}$. Growth was monitored at OD600, and it was observed that all ten isolates showed varied degree of growth when grown on MRS 
medium supplemented with concentration $(0.3 \%)$ of bile salt. From Table 4, it was observed that HM2 showed the highest value of OD600 (1.23) while Bn2 showed the lowest absorbance (0.689). Other isolates were in the range of 0.711 to 1.092 .

Table 2. Growth of LAB in $0.3 \%$ oxbile $^{a}$

\begin{tabular}{|c|c|}
\hline Isolate & OD60 \\
\hline YN & 0.961 \\
\hline CY & 0.711 \\
\hline YD & 1.092 \\
\hline FY & 0.933 \\
\hline Bn1 & 1.004 \\
\hline Bn2 & 0.689 \\
\hline HM1 & 0.777 \\
\hline HM2 & 1.23 \\
\hline HM3 & 0.867 \\
\hline HM4 & 0.822 \\
\hline
\end{tabular}

${ }^{\mathrm{a}}$ Titer plates were incubated at $37^{\circ} \mathrm{C}$ for $24 \mathrm{~h}$ anaerobically and growth was monitored at OD600 $\mathrm{nm}$

\subsubsection{Acid and Oxbile Challenge}

Survival of isolates after acid and oxbile stresses is shown in (Table 5). Showed viable counts $\left(\log ^{10} \mathrm{cfu} / \mathrm{mL}\right)$ of probiotic isolates at the beginning and end of acid and oxbile stress and percentage survival of the isolated strains in the acid and oxbile stress (Table 6). All ten isolates could survive and increased viability in acidic condition by 0.01 to $0.35 \log ^{10} \mathrm{cfu} / \mathrm{ml}$.

Table 3. Viable counts $(\log 10 \mathrm{cfu} / \mathrm{mL})$ of LAB isolates at the beginning and end of acid and oxbile stress experiments.

\begin{tabular}{|c|l|l|l|l|}
\hline Isolates & Acid stress $^{\mathrm{a}}$ & & Oxbile stress $^{\mathrm{b}}$ & \\
\hline & $0 \mathrm{~min}$ & $60 \mathrm{~min}$ & $0 \mathrm{~min}$ & $60 \mathrm{~min}$ \\
\hline YN & $9.08 \pm 0.06$ & $9.11 \pm 0.03$ & $9.29 \pm 0.03$ & $9.34 \pm 0.01$ \\
\hline CY & $8.26 \pm 0.15$ & $8.29 \pm 0.25$ & $8.81 \pm 0.21$ & $9.17 \pm 0.08$ \\
\hline YD & $9.23 \pm 0.05$ & $8.98 \pm 0.16$ & $9.18 \pm 0.09$ & $9.27 \pm 0.03$ \\
\hline FY & $8.55 \pm 0.08$ & $8.56 \pm 0.10$ & $8.84 \pm 0.01$ & $9.11 \pm 0.06$ \\
\hline Bn1 & $9.12 \pm 0.00$ & $9.31 \pm 0.06$ & $9.00 \pm 0.00$ & $9.17 \pm 0.03$ \\
\hline Bn2 & $7.95 \pm 0.29$ & $6.00 \pm 0.00$ & $7.03 \pm 0.00$ & $7.47 \pm 0.19$ \\
\hline HM1 & $7.60 \pm 0.46$ & $7.69 \pm 0.46$ & $7.40 \pm 0.32$ & $8.26 \pm 0.15$ \\
\hline HM2 & $9.70 \pm 0.02$ & $9.92 \pm 0.02$ & $8.77 \pm 0.04$ & $9.37 \pm 0.05$ \\
\hline HM3 & $8.90 \pm 0.19$ & $8.98 \pm 0.09$ & $9.00 \pm 0.26$ & $9.33 \pm 0.06$ \\
\hline HM4 & $7.11 \pm 0.26$ & $7.20 \pm 0.46$ & $8.34 \pm 0.28$ & $8.37 \pm 0.23$ \\
\hline
\end{tabular}

(a) cells kept for $60 \mathrm{~min}$ in MRS broth ( $\mathrm{pH} 2.0$ at $37^{\circ} \mathrm{C}$ ).

b cells let with $0.3 \%$ (w/v) oxbile in MRS broth ( $\mathrm{pH} 6.5$ at $37^{\circ} \mathrm{C}$ ). 


\section{Macrothink}

Table 4. Percentage survival of the LAB isolates strains in the acid and oxbile stress

\begin{tabular}{|c|c|c|}
\hline Isolates & \multicolumn{2}{|c|}{ Survival (\%) } \\
\hline & Acid stress $^{\mathrm{a}}$ & Acid stress $^{\mathrm{a}}$ \\
\hline YN & 3 & 5 \\
\hline CY & 3 & 36 \\
\hline YD & 25 & 9 \\
\hline FY & 1 & 27 \\
\hline Bn1 & 9 & 17 \\
\hline Bn2 & 35 & 44 \\
\hline HM1 & 9 & 86 \\
\hline HM2 & 22 & 60 \\
\hline HM3 & 8 & 33 \\
\hline HM4 & 9 & 3 \\
\hline
\end{tabular}

\subsection{Determination of Adhesion Level by a Co-sedimentation Assay}

Ten species of bacteria adhered to rice starch granules with in $60 \mathrm{~min}$ of exposure to the granules (Figure 1.).Bn1 and HM2 adhered well to rice starch with a total of $79 \%$ and $77 \%$ of the cells adhering (highly adherent). YN=70\%, CY=48\%, FY=55\%, HM1=61, 5\%, HM3 $=65 \%$, and HM4=50, 5\% species adhered less well (moderate adherent). YD=20\% and Bn2 $=18 \%$ species adhered less than $40 \%$ (Poorly adherent). It was observed that the type of rice from which the resistant starch was produced have no effect on the percent adhesion of probiotic LAB isolates.

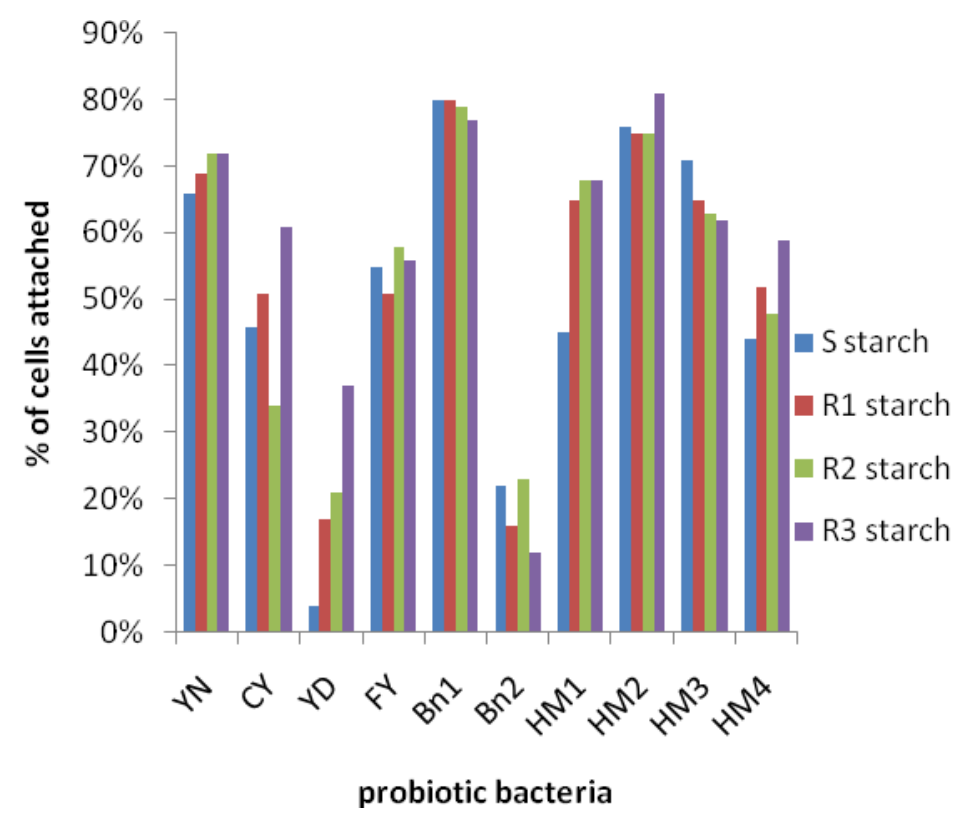

Figure 1. Percentage of cells adhering to resistant rice starch ( $\mathrm{S}=$ soluble starch, $\mathrm{R} 1=$ white rice starch, R2=unpolished brown rice starch, R3=grow Cambodian brown rice starch) 


\section{Macrothink}

\subsection{Effect of Time on Adhesion of Probiotics to Resistant Rice Starch}

The influence of time on the adhesion of bacteria to starch granules seems clear with all samples Through the next charts (figure. 2) for example, Bn1 had the highest percentage of adhesion at the time of $60 \mathrm{~m}(80 \%)$, while we noted a gradual decline with decrease of time (79\% at $45 \mathrm{~m}, 71 \%$ at $30 \mathrm{~m}$, and $60 \%$ at $15 \mathrm{~m}$ ).

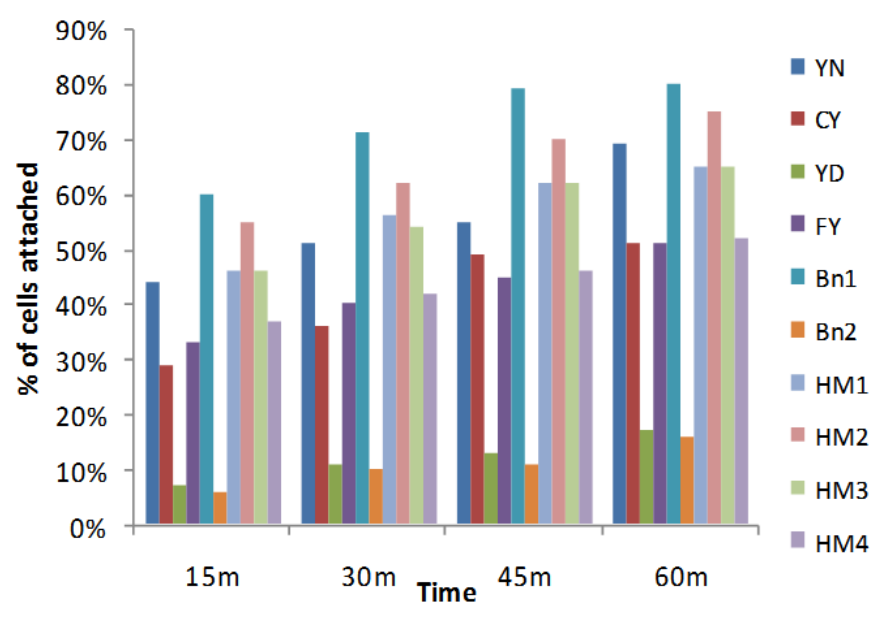

Figure 2. Effect of time on percentage adhesion of LAB to rice resistant starch

3.5 The Effect of the Concentration of Substrate from Rice Starch on the Adhesion of Probiotics

The influence of the concentration of substrate (10 g liter ${ }^{-1}, 15$ g liter $^{-1}$, and $\left.20 \mathrm{~g} \mathrm{liter}^{-1}\right)$ on adhesion was examined. As you see the increase in the concentration of starch granules did not observe a significant difference in adhesion (Figure 3.)

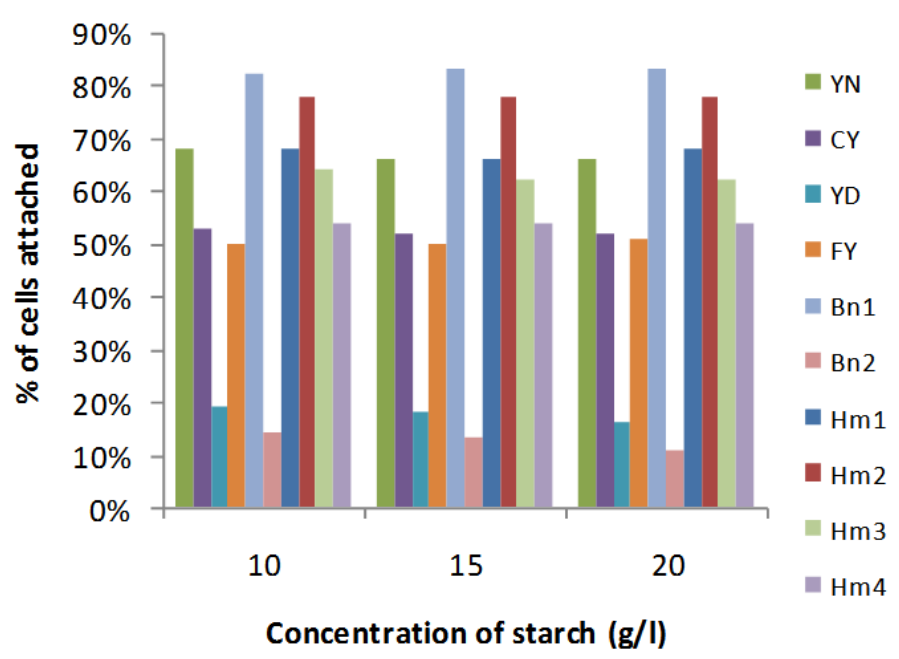

Figure 3. Effect of substrate concentration on adhesion of probiotic bacteria to resistant starch 3.6 The effect of Temperature on Attachment of Probiotics to Rice Starch.

The effect of temperature (body temperature bt, heat-killed cells hk, room temperature rt) on attachment was examined. There are decline in the proportion of cells seen in our trials 


\section{Macrothink}

adhere to granular starch at $100^{\circ} \mathrm{C}$ compared with $37^{\circ} \mathrm{C}$ and room temperature(figure4.).

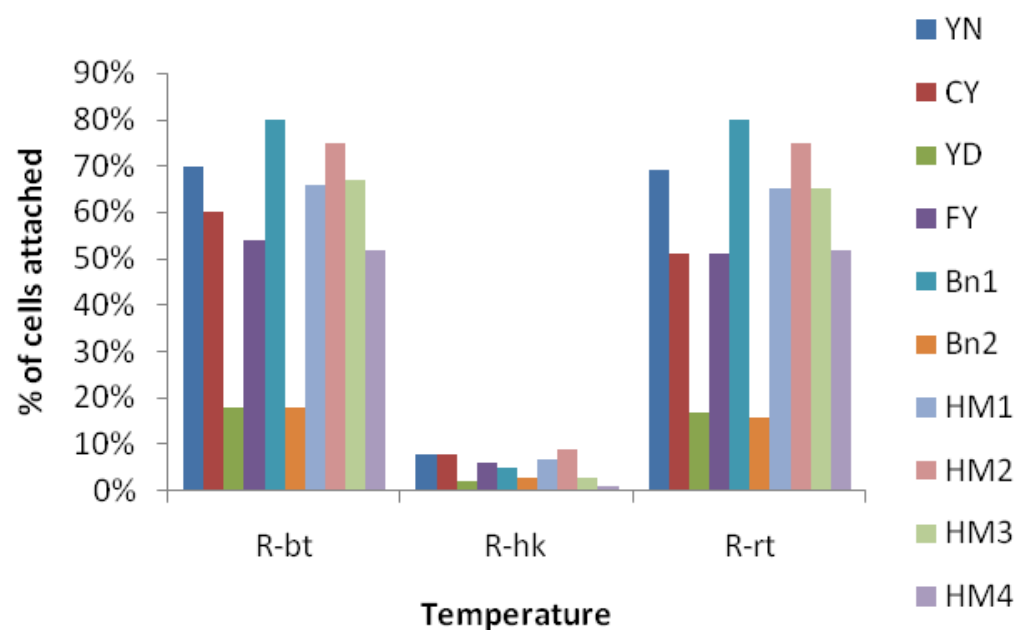

Figure 4. Effect of temperature on adhesion of probiotic to RRS

\subsection{The effect of the Bacterial Growth Phase on Adhesion of Probiotic Bacteria to Rice Starch}

The effect of the growth phase on adhesion was examined (figure 5.). Adhesion of the bacteria to starch was determined with cells that were in the late lag phase (ll=6 h), the exponential phase $(\mathrm{le}=24 \mathrm{~h}$ ), and the mid-stationary phase (ms=36 h).Maximum adhesion occurred in the late exponential phase.

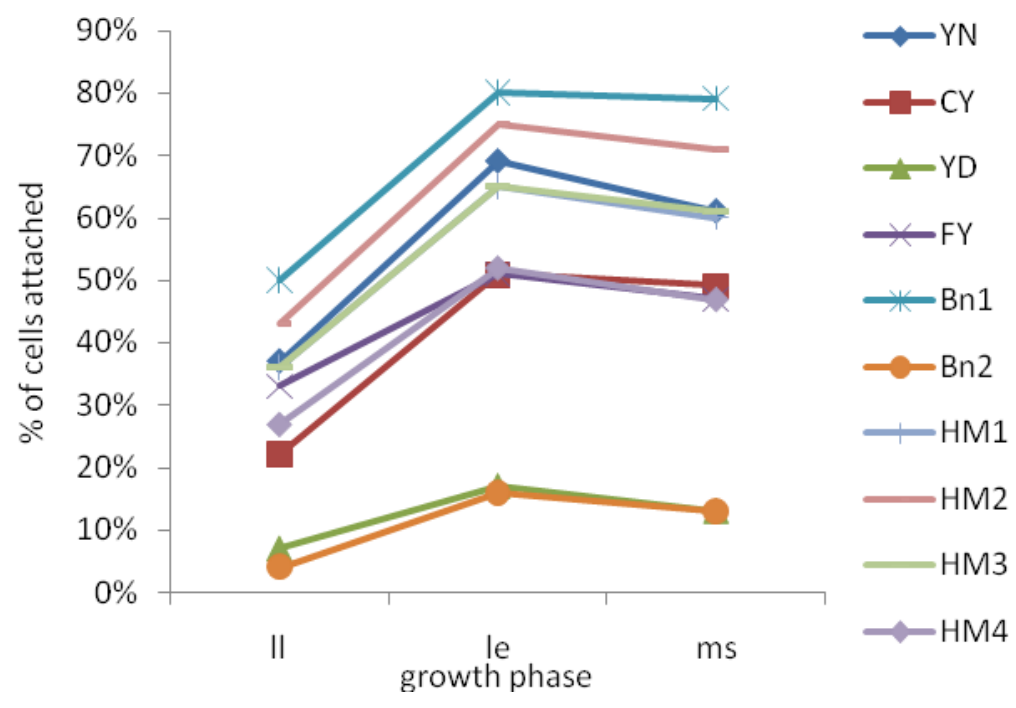

Figure 5. Effect of growth phase on adhesion of cells to RRS

\section{Discussion}

The use of chemical supplements or antibiotic growth promoters in animals are replaced by Probiotics as health supplements in food and feeds (Kosin \& Rakshit, 2006). Lactobacillus and Bifidobacterium can restore the normal balance of microbial populations in the intestine 
(Shah, 2006). One of the technological hurdles that need to be solved is the survival of probiotic during processing. Viability and stability of probiotics has been both a marketing and technological challenge for industrial producers. Probiotics to be functional, it must be sustainable and adequate doses (Galdeano \& Perdigón, 2004).

Prebiotics such as resistant starch can be included with probiotics (synbiotic system) as a composite carrier matrix system to increase their survival during processing (Kosin \& Rakshit, 2006). Some starches can arrive to the colon as fermentable carbohydrate sources for intestinal bacteria without digestion when they are passing through the human small intestine (Cummings \& Macfarlane, 1997). Additionally, resistant starch provides the perfect surface for adherence of the probiotics to the starch granule while processing, storage and transit through the upper regions of the gastrointestinal tract (Crittenden et al., 2001).

It was reported that adhesion of different species of probiotics such as Bifidobacterium spp to native maize, potato, oat, and barley starch granule showed that starch adhesion was not characteristic of all the bifidobacteria tested (Crittenden et al., 2001). Our finding indicated that probiotic bacteria isolated from the various source showed different adhesion level to resistant starch extracted from three type of rice using a co-sedimentation assay. Ten species of bacteria adhered to rice starch granules within 60 min of exposure to the granules. $\mathrm{Bn} 1$ and HM2 adhered well to rice starch with a total of $79 \%$ and $77 \%$ of the cells adhering (highly adherent). YN=70\%, CY=48\%, FY=55\%, HM1=61, 5\%, HM3=65\%, and HM4=50, $5 \%$ species adhered less well (moderate adherent). YD=20\% and $\mathrm{Bn} 2=18 \%$ species adhered less than $40 \%$ (Poorly adherent), adhesion to starch granules was measured by a co sedimentation assay.

The relationship between the time and adhesion is positive correlation (Yavuzdurmaz, 2007). Our findings may also indicate that the influence of time on the adhesion of bacteria to starch granules seems clear with all samples, for example, Bn1 had the highest percentage of adhesion at the time of $60 \mathrm{~m}(80 \%)$, while we noted a gradual decline with decrease of time (79\% at $45 \mathrm{~m}$, $71 \%$ at $30 \mathrm{~m}$, and $60 \%$ at $15 \mathrm{~m}$ ), that agreed with previous work by Fernando et al. (2011) which; studied attachment of Bifidobacteria and Lactobacilli to dietary fiber fractions within 15 to 60 min., and showed positive relationship between time and attachment percentage of Bifidobacteria and Lactobacilli to rice fiber . Imam and Harry (1991) found the number of Lactobacillus amylovorus cells bound to cornstarch granules increased with time, reaching a maximum of 60 to $75 \%$ in $30 \mathrm{~min}$.

Interestingly, relationship between the surface area obtainable for bound bacteria and concentrations of the substrate is positively. However, the present study did not observe a significant difference in adhesion with an increase in the concentration of starch granules.Our result agreed with Fernando et al. (2011), but it Inconsistent with Imam and Harry (1991) who found that; binding of L. amylovorus cells to granules increased proportionally with the concentration of starch present in the incubation mixture.

High temperatures will deactivate the enzymes of cells and effect on cell attachment. This can be the pillars of explains the decline in the proportion of cells seen in our trials adhere to granular starch at $100{ }^{\circ} \mathrm{C}$ compared with $37^{\circ} \mathrm{C}$ and room temperature. High temperatures 
kill microorganisms, this observation refers that the micro-organisms that live cells are probably to bond with the granular than dead cells. Optimum growth temperature for these microorganisms and body temperature $\left(37^{\circ} \mathrm{C}\right)$ was perfect temperature to adhere (Fernando et al., 2011; Yavuzdurmaz, 2007).

The influence of the growth phase on adhesion was studied. Adhesion of the bacteria to starch was determined with cells at (6 h, 24h, and 36h). So this notice confirmed that maximum adhesion happen in the late exponential phase when enzyme activity is a maximum (Crittenden et al., 2001; Fernando et al., 2011), it is similar result which reported by Fernando et al. (2011), however there is no significantly different (P. 0.05) in the percentages of cells adhering to the starch granules for cells harvested in the lag phase, the exponential phase, and the stationary phase (Crittenden et al., 2001). The effect of bacterial growth phase on adhesion was carried out with highly adherent strain E.ludwigii. Cells in stationary phase were capable to adhere more than $60 \%$. In contrast, cells in exponential growth phase reached only 35\% of cells adhesion (Schoebitz et al. 2009).

\section{Conclusion}

The present study focused on adhesion of probiotic to resistant starch and investigating factors affecting on adhesion of probiotics to resistant rice starch. The adhesion level was measured by a co-sedimentation assay. In addition, this study had been shown that probiotic isolates have different level of attachment to several type of resistant rice starch. Bacterial adhesion is complicated, which involve the bacteria, substrate and environment. Adhesion to starch granular may not be influenced by concentration of substrate from rice starch, but the Adhesion level was registered clear difference among different time, temperature, and growth phase.

Bacterial adhesion to starch may also supply benefits in new probiotic technologies that promote submission of viable and metabolically active probiotics to the intestinal tract. It might be possible to trade on adhesion of probiotic bacteria to starch granules in microencapsulation technology and for synbiotic food applications such as bakery products.

\section{Acknowledgement}

This study has been supported by the Faculty of Science and Technology, Universiti Sains Islam Malaysia

\section{References}

Anal, A. K., \& Singh, H. (2007). Recent advances in microencapsulation of probiotics for industrial applications and targeted delivery. Trends Food Science \& Technology, 18, 240-251. http://dx.doi.org/10.1016/j.tifs.2007.01.004

Çakır, İ. (2003). Determination of some probiotic properties on Lactobacilli and Bifidobacteria. Ankara University Thesis of Ph.D.

Chou, L. S., \& Weimer, B. (1999). Isolation and characterization of acid and bile tolerantisolates from strains of Lactobacillus acidophilus.Journal of Dairy Science., 82, 
23-31. http://dx.doi.org/10.3168/jds.S0022-0302(99)75204-5

Crittenden, R., Laitila, A., Forssell, P., M.att, o. J., Saarela, M., Mattila-Sandholm, T., \& Myll.arinen, P. (2001). Adhesion of bifidobacteria to granular starch and implication in probiotic technologies. Journal of Microbiology \& Technology, 67, 3469-3475.

Cummings, J. H., \& Macfarlane, G. T. (1997). Colonic microflora: nutrition and health. Nutrition, 13, 476-478. http://dx.doi.org/10.1016/S0899-9007(97)00114-7

Fernando, W., Flint, S., Charles, S., Ranaweera, K. D. S., \& Bamunuarachchi, A. (2011). Environmental Factors Affecting the Adhesion of Probiotics to Rice Fiber Fractions. Food Di, 2, 1-3.

Galdeano, C. M., \& Perdigón, G. (2004). Role of viability of probiotic strains in their persistence in the gut and in mucosal immune stimulation. J. Appl. Microbiol, 97, 673-681. http://dx.doi.org/10.1111/j.1365-2672.2004.02353.x

Gibbs, B. F., Kermasha, S., Ali, I., \& Mulligan, C. H. (1999). Encapsulation in the food industry: A review. Int. J. Food Sci. Nutr, 50, 213-224. http://dx.doi.org/10.1080/096374899101256

Imam Syed, H., \& Harry-O'kuru, R. E. (1991). Adhesion of Lactobacillus amylovorus to Insoluble and Derivatized Cornstarch Granules. Appl Environ Microbiol, 57(4), 1128-1133.

Kheadr, E. E. (2006). Impact of acid and oxgall on antibiotic susceptibility of probiotic Lactobacilli. African Journal of Agricultural Research, 1, 172-181.

Kosin, B., \& Rakshit, S. K. (2006). Criteria for Production of Probiotics. Food Technology. Biotechnology, 44(3), 371-379.

Macfarlane, G. T., \& Englyst, H. N (1986). Starch utilization by the human large intestinal $\begin{array}{lllll}\text { microflora. } & \mathrm{J} & \text { Appl } & \text { Bacteriol, } & \text { 60, 201. }\end{array}$ http://dx.doi.org/10.1111/j.1365-2672.1986.tb01073.x

Mortazavian, A. M., Azizi, A., Ehsani, M. R., Razavi, S. H., Mousavi, S. M., Sohrabvandi, S., \& Reinheimer, J. A. (2008). Survival of encapsulated probiotic bacteria in Iranian yogurt drink (Doogh) after the product exposure to simulated gastrointestinal conditions. Milchwissenschaft, 63 (4), 427-429.

Myllarinen, T. P., Crittenden, R., Mogensen, G., Fonden, R., \& Saarela, M. (2002). Technological challenges for future probiotic foods. Int. Dairy J., 12, 173-182.http://dx.doi.org/10.1016/S0958-6946(01)00099-1

Prasad, J., Gill, H., Smart, J., \& Gopal, P. K. (1998). Selection and Characterization of Lactobacillus and Bifidobacteriumstrains for use as probiotic. International Dairy Journal 8, 993-1002. http://dx.doi.org/10.1016/S0958-6946(99)00024-2

Quwehand, A. C., Kirjavainen, P. V., Shortt, C., \& Salminen, S. (1999). Probiotics: Mechanisms and established effects. International Dairy Journal, 9, 43-52.31. 


\section{Macrothink}

Journal of Biology and Life Science ISSN 2157-6076 2013, Vol. 4, No. 1

Roger, V., Fonty, G., Komisarczul-Bony, S., \& Gouet, P. (1990). Effects of physicochemical factors on the adhesion to cellulose avicel of the ruminal bacteria Ruminococcusflavefaciens and Fibro bactersuccinogenes subsp. succinogenes. Appl Environ Microbiol, 56 (10),30813087.

Sajilata, M. G., Singhal, R. S., \& Kulkarni, P. R. (2006). Resistant starch - a review. Comprehensive Reviews in Food Science \& Food Safety, 5(1), 1-17. http://dx.doi.org/10.1111/j.1541-4337.2006.tb00076.x

Schoebitz, M., Simonin, H., \& Poncelet, D. (2009). Rhizobacteria adhesion to starch granules. Poster, P88 - page 1

Shah, N. P. (2006). Microorganisms and health attributes (probiotics). In R. C. Chandan (Ed.), Manufacturing yogurt and fermented milks. Iowa, USA, Blackwell Publishing Professional, 341-354.

Silvi, S., Rumney, C. J., Cresci, A., \& Rowland, I. R. (1999). Resistant starch modifies gut microflora and microbial metabolism in human flora-associated rats inoculated with faeces from Italian and UK donors. $J$ Appl Microbiol, 86, 521-530. http://dx.doi.org/10.1046/j.1365-2672.1999.00696.x

Tancula, E., Feldhaus, M. J., Bedzyk, L. A., \& Salyers, A. A. (1992). Location and characterization of genes involved in binding of starch to the surface of Bacteroides thetaiotaomicron. J Bacteriol, 174, 5609-5616.

Vonk, R. J., Hagedoorn, R. E., de Graaff, R., Elzinga, H., Tabak, S., Yang, Y. X., \& Stellaard, F. (2000). Digestion of so-called resistant starch sources in the human small intestine. Am $J$ Clin Nutr, 72, 432-438.

Yavuzdurmaz, H. (2007). Isolation, Characterization, Determination Of Probiotic Properties Of Lactic Acid Bacteria From Human milk. Thesis (Master Of Science)

\section{Copyright Disclaimer}

Copyright reserved by the author(s).

This article is an open-access article distributed under the terms and conditions of the Creative Commons Attribution license (http://creativecommons.org/licenses/by/3.0/). 